\title{
Peremajaan Berbasis Masyarakat pada Kawasan Eks Lokalisasi Putat Jaya Surabaya
}

\author{
Community-based Urban Renewal in the Putat Jaya Surabaya Red-Light District
}

\author{
Wienda Novita Sari ${ }^{1}$, Petrus N. Indradjati²
}

Diterima: 28 November 2019

Disetujui: 10 Juli 2020

\begin{abstract}
Abstrak: Pendekatan Peremajaan kota umumnya dilakukan dengan intervensi fisik maupun ekonomi. Pendekatan pembangunan/peremajaan berbasis masyarakat dianggap menuai hasil jangka panjang, oleh karenanya jarang dilakukan. Kajian peremajaan berbasis masyarakat sangat penting dilakukan karena dampaknya yang lebih berkelanjutan. Peremajaan kawasan eks lokalisasi Putat Jaya Surabaya dilakukan sebagai tanggapan atas tekanan persoalan dan perubahan sosial dan ekonomi melalui penutupan kawasan lokalisasi Dolly dan Jarak (Putat Jaya). Pemerintah Kota Surabaya memilih pendekatan peremajaan berbasis masyarakat meskipun belum memiliki panduan mekanisme pelaksanaannya. Penelitian ini bertujuan untuk mengevaluasi dan merumuskan mekanisme peremajaan berbasis masyarakat, sehingga dapat menjadi acuan dalam pelaksanaan peremajaan berbasis masyarakat. Hasil penelitian menunjukkan bahwa upaya yang telah dilakukan Pemerintah Kota Surabaya belum sepenuhnya memenuhi prinsip-prinsip peremajaan berbasis masyarakat dimana masyarakat memiliki peran sentral dalam penyusunan dan penerapan rencana serta monitoring hasil peremajaan secara partisipatif.
\end{abstract}

Kata Kunci: peremajaan, pembangunan berbasis masyarakat, Putat Jaya, lokalisasi

\begin{abstract}
The urban renewal approach is generally carried out with both physical and economic appoach. A community-based development/urban renewal approach is used for long-term results, therefore it is rarely done. Community based urban renewal study is very important because the impact is more sustainable. Urban renewal of red-light district Putat Jaya Surabaya is carried out to resolve the pressure and social economic change, which is the closing of Dolly and Jarak (Putat Jaya). The Government of Surabaya has been using a community based approach in conducting the renewal, but in doing so the Government of Surabaya has no reference, especially the know-how mechanism of a community based development. This study aims to evaluate and formulate a community-based urban renewal mechanism, so that it can be a reference in the implementation of urban renewal. The results showed that the efforts made by the Surabaya of Government had not fully met the principles of community-based urban renewal where the community had a central role in the preparation and implementation of plans and monitoring of the results of urban renewal in a participatory manner.
\end{abstract}

Keywords: urban renewal, community-based development, mechanism, red-light district

\footnotetext{
1 Bappeda Kota Surabaya

2 Sekolah Arsitektur, Perencanaan dan Pengembangan Kebijakan, Institut Teknologi Bandung
}

Korespondensi: natalivan@ sappk.itb.ac.id 


\section{PENDAHULUAN}

Kota atau kawasan perkotaan selalu dikaitkan dengan kehidupan masyarakat modern yang dinamis, heterogen, padat dan multikultur sehingga memicu berbagai persoalan yang kompleks. Peremajaan merupakan tanggapan atas tekanan persoalan perubahan sosial dan ekonomi yang berakibat pada pengembangan fisik kota. Kota Surabaya sebagai salah satu kota metropolitan di Indonesia tidak lepas dari kompleksitas persoalan, dengan persoalan sosial utama yang dihadapi adalah terdapatnya aktivitas prostitusi. Pada tahun 2014 Pemerintah Kota Surabaya didukung oleh Kementerian Agama dan Pemerintah Provinsi Jawa Timur menutup kegiatan prostitusi pada kawasan lokalisasi terbesar di Kota Surabaya, yaitu kawasan Dolly dan Jarak (selanjutnya disebut lokalisasi Putat Jaya). Pasca penutupan lokalisasi Pemerintah Kota Surabaya melakukan peremajaan kawasan. Pemerintah Kota Surabaya juga telah menyusun Grand Design Penataan Kawasan Eks Lokalisasi Kelurahan Putat Jaya Kecamatan Sawahan yang antara lain menjelaskan bahwa peremajaan kawasan eks lokalisasi dilakukan dengan pendekatan pembangunan berbasis masyarakat.

Dalam pelaksanaannya, Pemerintah Kota Surabaya belum memiliki rujukan, khususnya mengenai mekanisme peremajaan berbasis masyarakat. Peremajaan kawasan yang telah dilaksanakan pada umumnya merupakan inisiasi dari Pemerintah Kota Surabaya dan belum sepenuhnya melibatkan masyarakat. Persoalan lainnya adalah belum tersedia informasi mengenai aktor-aktor yang memiliki pengaruh dan kepentingan dalam peremajaan serta belum teridentifikasinya kondisi sosial, ekonomi dan kelembagaan dalam masyarakat. Sejak dilakukan penutupan kawasan lokalisasi Putat Jaya pada tahun 2014 sampai dengan saat ini, peremajaan telah dilakukan baik dari aspek sosial, ekonomi maupun fisik berupa pelatihan keterampilan serta penyediaan ruang publik untuk usaha dan interaksi sosial. Oleh karena itu, sangat penting dilakukan kajian terkait proses peremajaan yang selama ini telah dilakukan untuk memberikan panduan yang lebih jelas untuk lebih mengarusutamakan masyarakat setempat dalam perbaikan lingkungan.

Sejarah perkembangan peremajaan kota tidak lepas dari isu perbaikan lingkungan perumahan, dimulai dengan persoalan bagaimana meningkatkan lingkungan yang layak dan sesuai standar, memenuhi kebutuhan rumah hingga motivasi fiskal terkait bagaimana mengembangkan kawasan sesuai dengan nilai lahan serta upaya peningkatan nilai lahan dan untuk mendapatkan manfaatan ekonomi yang optimal (Adams \& Hastings, 2001; Clark \& Wise, 2018; Couch, 1990; Taufiq et al., 2019). Pengertian peremajaan umumnya lebih menekankan pada upaya penanganan kawasan kumuh dan pembangunan fisik kembali dengan mempertimbangkan unsur-unsur lain seperti pelestarian kawasan sejarah (Couch et al., 2011). Dalam perkembangannya, peremajaan kota menjadi salah satu pendekatan dalam mengintervensi penggunaan lahan untuk peningkatan kualitas lingkungan perkotaan melalui kebijakan perbaikan persoalan sosial, ekonomi maupun lingkungan, peningkatan jejaring sosial dan pemberdayaan masyarakat serta memberikan manfaatan berbagai stakeholder (Adams \& Hastings, 2001; Wang et al., 2017; Zhang \& Li, 2016). Terdapat dua hal penting dalam pengertian peremajaan kota, pertama adalah upaya pembangunan kembali atau rehabilitasi atau perpaduan antara keduanya; kedua merupakan upaya untuk memperbaiki kondisi lingkungan perumahan yang dibawah standar (Lai et al., 2018). Istilah peremajaan kota mempunyai pengertian yang sama dengan regenerasi perkotaan (urban regeneration), pembangunan kembali perkotaan (urban redevelopment) maupun rehabilitasi perkotaan (urban rehabilitation), namun berbeda dalam hal skala (Zheng et al., 2014). Program peremajaan kota dapat dilakukan pada dua jenis perubahan, yaitu perubahan yang bersifat sebagian/kritis atau bersifat total. Dalam konteks kawasan, perubahan total memungkinkan perubahan struktur fisik dan morfologi kawasan kota. Pendekatan ini dikenal dengan pembangunan kembali kawasan perkotaan. Apabila tidak terkendali, perubahan total ini biasanya diikuti oleh dampak sosial negatif. Pada konteks pembangunan kembali kawasan perkotaan, pendekatan pembangunan berbasis 
masyarakat dalam peremajaan menjadi sangat penting. Dalam mekanismenya, kegiatan penataan ulang tidak hanya melibatkan unsur fisik dengan melakukan perubahan terhadap struktur dan morfologi kawasan, namun juga aspek nonfisik. Pelibatan masyarakat dalam peremajaan diperlukan pada proses perencanaan, dikaji dalam setiap tahapan, survei, proses analisis hingga produk perencanaan secara rasional. Produk peremajaan kota dapat berupa usaha peningkatan efektivitas dan efisiensi suatu kegiatan fungsional tertentu yang sama fungsinya dengan keadaan semua atau dengan mengubah kegiatan fungsional semula menjadi suatu bentuk kegiatan fungsional baru. Perubahan yang dihasilkan dari peremajaan merupakan outcome dari tuntutan kegiatan/ektivitas ekonomi ataupun kekuatan-kekuatan sosial.

Peremajaan kota berbasis masyarakat dianggap lebih berkelanjutan. Namun upaya perwujudannya sangat kompleks dan melibatkan tidak hanya komponen pembentuk sistem perencanaan, terkait sistem lahan, perumahan, infrastruktur, cagar budaya, perancangan kota, tetapi juga komponen pembentuk sistem sosial yang dalam prosesnya mencakup pelibatan berbagai stekholder dan peran serta masyarakat (Zheng et al., 2014). Kasus peremajaan 'dari bawah' (bottom up), mulai banyak diterapkan di beberapa negara, salah satunya menggunakan pendekatan perspektif institusional yang mendudukan kelembagaan sebagai kekuatan pendorong, pengembangan kebijakan yang memberi kerangka prosedural pelaksanaan peremajaan kota, dan ekplorasi relasi kekuatan (power relation), biaya manfaatan dari aktor terkait seperti permerintah lokal, masyarakat yang tinggal di kawasan peremajaan, masyarakat umum dan pihak ketiga atau pengembang (Tian \& Yao, 2018). Peneliti yang lain menekankan keseimbangan kepentingan dari pemerintah, penghuni dan pengembangan dalam peremajaan kota (Lai et al., 2018; Wang et al., 2017).

Tulisan ini mengeksplorasi prinsip-prinsip pembangunan berbasis masyarakat dalam peremajaan dan pelaksanaan peremajaan dengan pendekatan pembangunan berbasis masyarakat pada kawasan eks lokalisasi Putat Jaya Surabaya sebagai dasar pengembangan pendekatan dalam peremajaan berbasis masyarakat. Bagian pertama tulisan ini, mengeksplorasi konteks wilayah untuk identifikasi kondisi empiris kawasan eks lokalisasi Putat Jaya. Bagian kedua membahas aktor yang berpengaruh dan berkepentingan, preferensi masyarakat serta potensi dan persoalan kawasan. Bagian akhir membahas proses peremajaan kawasan eks lokalisasi Putat Jaya dan membandingkannya dengan mekanisme peremajaan berbasis masyarakat, sehingga dapat diambil langkah dalam mewujudkan peremajaan berbasis masyarakat pada kawasan eks lokalisasi Putat Jaya.

\section{METODE}

Pendekatan peremajaan berbasis masyarakat mengalami perubahan seiring pergeseran paradigma pembangunan. Dari strategi pembangunan yang menekankan pertumbuhan dan distribusi, teknologi tepat guna, kebutuhan dasar, pembangunan berkelanjutan dan pemberdayaan ke paradigma pembangunan pemerataan, ketergantungan, pembangunan berbasis masyarakat dan pembangunan manusia (Mardikanto, 2010). Dalam pembangunan berbasis masyarakat, masyarakat lokal menjadi fokus/pusat yang perlu diberdayakan untuk berpartisipasi dalam proses pembangunan mereka (Wedchayanon \& Chorkaew, 2014). Teori ini menyatakan bahwa proses pembangunan harus berorientasi pada peningkatan kualitas hidup manusia, bukan pada pertumbuhan ekonomi melalui pasar maupun memperkuat negara. Pembangunan yang berpusat pada rakyat lebih menekankan pada pemberdayaan, yang memandang inisiatifkreatif dari rakyat sebagai sumber dalam pembangunan dan memandang kesejahteraan material dan spiritual sebagai tujuan yang akan dicapai proses pembangunan.

Peremajaan berbasis masyarakat erat kaitannya dengan mekanisme pembangunan berbasis masyarakat yang menurut Mikkelsen terdiri dari tahapan penetapan dan pengenalan wilayah kerja, sosialisasi kegiatan, penyadaran masyarakat dan pengorganisasian masyarakat (Mikkelsen, 2001). Theresia, dkk mengelompokkan 
pembangunan berbasis masyarakat melalui tahapan seleksi lokasi, sosialisasi, proses identifikasi, penyusunan kegiatan kelompok, penerapan rencana kegiatan kelompok, monitoring dan evaluasi partisipatif serta pemandirian masyarakat (Theresia et al., 2014). Dalam literatur lain, Mardikanto menjelaskan tahapan kegiatan pembangunan berbasis masyarakat diawali seleksi lokasi dan sosialisasi, diikuti tahap lanjut dalam proses pembangunan berbasis masyarakat yaitu pelaksanaan kegiatan, advokasi dan politisasi kebijakan (Mardikanto, 2010).

Peremajaan berbasis masyarakat pada dasarnya adalah peremajaan yang dalam prosesnya (perencanaan, pelaksanaan serta pengawasan dan pengendalian) bertitik tolak pada kebutuhan masyarakat, direncanakan dan dilaksanakan oleh masyarakat dengan memanfaatkan potensi sumber daya yang ada dan dapat diakses oleh masyarakat setempat. Dalam penelitian ini, mekanisme dimaknai sebagai cara kerja untuk mencapai pelaksanaan peremajaan berbasis masyarakat pada kawasan eks lokalisasi Putat Jaya. Berdasarkan tinjauan peraturan perundangan terkait penataan ruang dan sintesis literatur terkait peremajaan dan pembangunan berbasis masyarakat (Korten, 1984; Mardikanto, 2010; Mikkelsen, 2001; Theresia et al., 2014; Tian \& Yao, 2018; Wedchayanon \& Chorkaew, 2014) dirumuskan mekanisme peremajaan berbasis masyarakat dengan mensintesiskan substansi peremajaan dan substansi pembangunan berbasis masyarakat dalam rangkaian proses perencanaan, pelaksanaan serta pengawasan dan pengendalian. Mekanisme dan prasayarat dalam Tabel 1 menjadi kerangka analisis yang akan digunakan untuk menilai sejauhmana peremajaan yang dilakukan sudah berbasis masyarakat.

Tabel 1. Prasyarat dan Mekanisme Peremajaan Berbasis Masyarakat

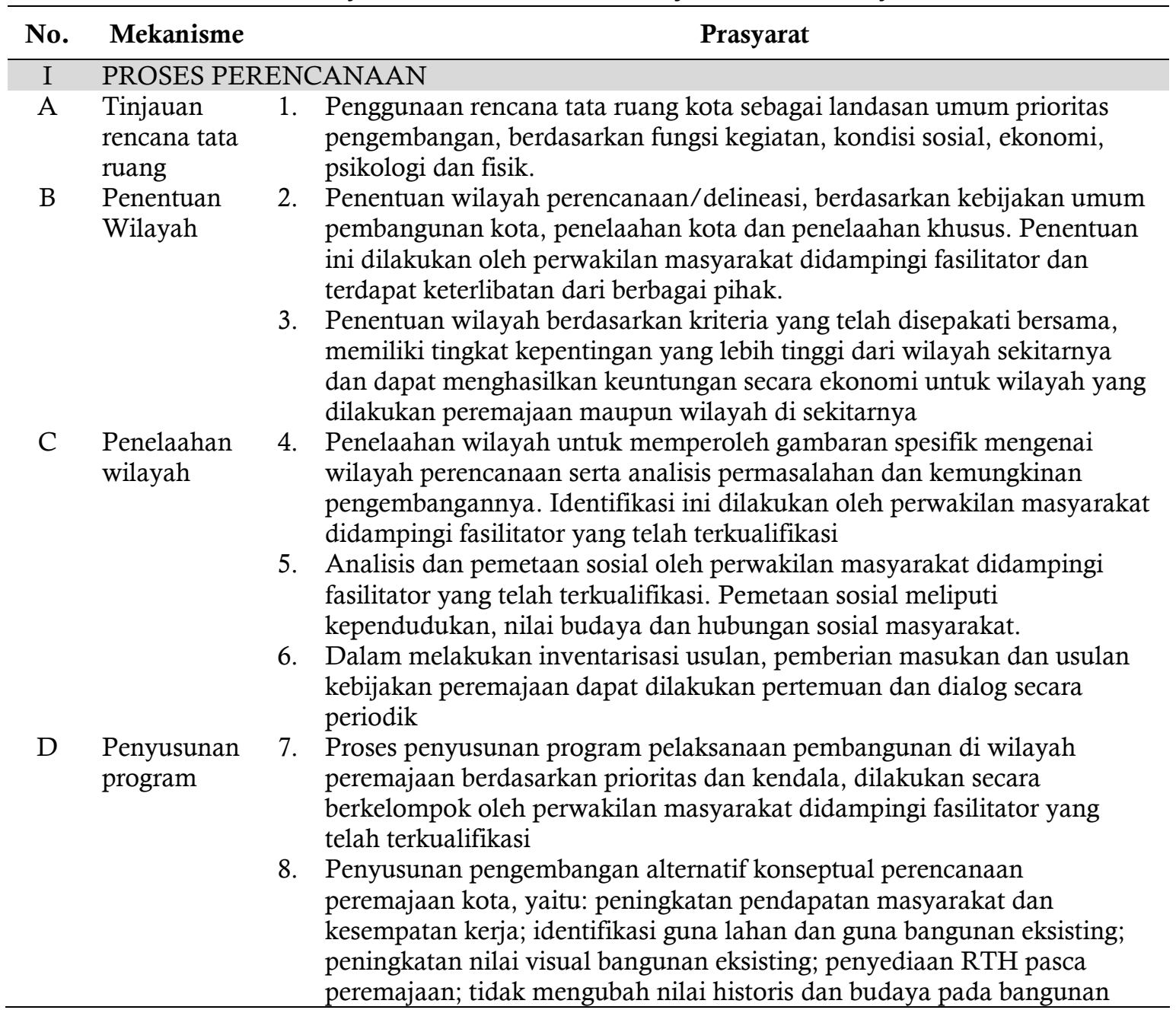




\begin{tabular}{|c|c|c|}
\hline No. & Mekanisme & Prasyarat \\
\hline $\mathrm{E}$ & Sosialisasi & $\begin{array}{l}\text { yang terdapat di kawasan peremajaan; peningkatan kualitas lingkungan } \\
\text { fisik di sekitarnya dan pengurangan permasalahan fisik lingkungan; } \\
\text { penyediaan/penataan kembali sarana yang berkaitan dengan pergerakan } \\
\text { 9. Mekanisme pembiayaan dapat dilakukan dengan sumber dana dari } \\
\text { pemerintah, swasta (sponsor, kerja sama, CSR) maupun swadaya } \\
\text { masyarakat } \\
\text { 10. Sosialisasi kegiatan kepada seluruh masyarakat } \\
\text { 11. Penyediaan akses kepada sumber daya pendukung lainnya } \\
\text { 12. Terdapat ragam dan efektivitas stakeholder yang terlibat }\end{array}$ \\
\hline II & PROSES PEL & AKSANAAN \\
\hline $\mathrm{F}$ & $\begin{array}{l}\text { Pelaksanaan } \\
\text { peremajaan } \\
\text { berbasis } \\
\text { masyarakat }\end{array}$ & $\begin{array}{l}\text { 13. Penerapan rencana kegiatan kelompok yang telah disusun dengan } \\
\text { sistematika pelaksanaan yang rasional, } \\
\text { 14. Penyadaran masyarakat melalui kegiatan pelatihan maupun } \\
\text { pembangunan berbasis kegiatan } \\
\text { 15. Adanya kebersamaan dalam pemanfaatan } \\
\text { 16. Terdapat lembaga yang efektif dalam pelaksanaan pembangunan }\end{array}$ \\
\hline III & PROSES PEN & GAWASAN DAN PENGENDALIAN \\
\hline G & $\begin{array}{l}\text { Pengawasan } \\
\text { pengendalian } \\
\text { peremajaan } \\
\text { berbasis } \\
\text { masyarakat }\end{array}$ & $\begin{array}{l}\text { 17. Monitoring dan evaluasi partisipatif } \\
\text { 18. Pemandirian masyarakat berupa pendampingan untuk menyiapkan } \\
\text { masyarakat agar benar-benar mampu mengelola kegiatannya secara } \\
\text { mandiri } \\
\text { 19. Pengorganisasian masyarakat dan advokasi kebijakan } \\
\text { 20. Politisasi kebijakan }\end{array}$ \\
\hline
\end{tabular}

Sumber: Korten, 1984; Mardikanto, 2010; Mikkelsen, 2001; Theresia et al., 2014; Tian \& Yao, 2018; Wedchayanon \& Chorkaew, 2014

Penelitian ini mengeksplorasi mekanisme peremajaan berbasis masyarakat dengan metode kualitatif. Metode ini dipilih karena permasalahan perumusan mekanisme peremajaan berbasis masyarakat pada kawasan eks lokalisasi Putat Jaya Surabaya bersifat kompleks dan dinamis sehingga perlu dipahami situasi sosial serta pola-pola/fenomena yang terjadi di lapangan. Populasi atau situasi sosial dalam penelitian ini adalah masyarakat sebagai aktor yang terlibat dalam peremajaan berbasis masyarakat serta penduduk di Rukun Warga (RW) yang berdekatan dengan kawasan eks lokalisasi Putat Jaya, yaitu RW 03, RW 06, RW 10, RW 11 dan RW 12 Kelurahan Putat Jaya Surabaya. Kelima RW tersebut merupakan wilayah terdampak aktivitas lokalisasi Putat Jaya, yang disebut dengan Ring-1 (berdasarkan hasil wawancara). Dalam penelitian ini, responden dipilih secara purposive dengan menggunakan snowball sampling. Informan terdiri dari tokoh di instansi Pemerintah Kota Surabaya dan lingkungan masyarakat.

\section{Teknik Pengumpulan Data}

Pengumpulan data dari sumber primer dilakukan dengan survei lapangan atau observasi/pengamatan langsung serta wawancara, sedangkan pengumpulan data dari sumber sekunder dilakukan melalui kajian literatur serta survei instansional ke Pemerintah Kota Surabaya. Penelitian ini juga menggunakan teknik triangulasi yang dimaksudkan untuk mengumpulkan data sekaligus menguji kredibilitasnya, sehingga dapat diketahui apakah penelitian telah dilakukan dengan benar dan akurasi laporan yang disampaikan (Creswell, 2014). Dalam penelitian ini, triangulasi teknik dilakukan melalui wawancara, observasi dan dokumentasi, khususnya untuk narasumber dari tokoh masyarakat. Triangulasi sumber, dilakukan baik pada wawancara tokoh masyarakat maupun wawancara instansional. 


\section{Teknik Analisis}

Analisis yang dilakukan terdiri dari tiga teknik yaitu analisis stakeholder, analisis taksonomi dan analisis perbandingan tetap. Stakeholder analysis, merupakan proses analisis data kualitatif untuk menentukan kepentingan dan pengaruh stakeholder tertentu dalam pengembangan maupun penerapan kebijakan atau program (Schmeer, 2000). Teknik analisis taksonomi dalam penelitian ini digunakan untuk mengidentifikasi preferensi masyarakat dalam peremajaan kawasan eks lokalisasi Putat Jaya. Teknik analisis perbandingan tetap atau constant comparative analysis, merupakan prosedur komparasi untuk mencermati padu tidaknya data dengan konsep-konsep dan kategori-kategori yang dikembangkan, padu tidaknya generalisasi atau teori dengan data yang tersedia, serta padu tidaknya keseluruhan temuan penelitian dengan kenyataan lapangan yang tersedia (Chun Tie et al., 2019). Teknik ini digunakan untuk merumuskan potensi dan persoalan peremajaan kawasan eks lokalisasi Putat Jaya serta rekomendasi peremajaan berbasis masyarakat pada kawasan eks lokalisasi Putat Jaya Surabaya, dengan memperbandingkan mekanisme peremajaan berbasis masyarakat dan kondisi empiris peremajaan pada kawasan eks lokalisasi Putat Jaya.

\section{HASIL DAN PEMBAHASAN}

\section{Karakteristik Kawasan Eks Lokalisasi Putat Jaya Surabaya}

Prostitusi di Kota Surabaya pertama kali dibawa oleh bangsa Jepang sebelum terjadinya perang kemerdekaan, berlokasi di Kembang Jepun. Perkembangan kota menyebabkan lokasi prostitusi mengalami beberapa kali perpindahan, hingga pada akhirnya terbentuk kawasan eks lokalisasi di Putat Jaya.

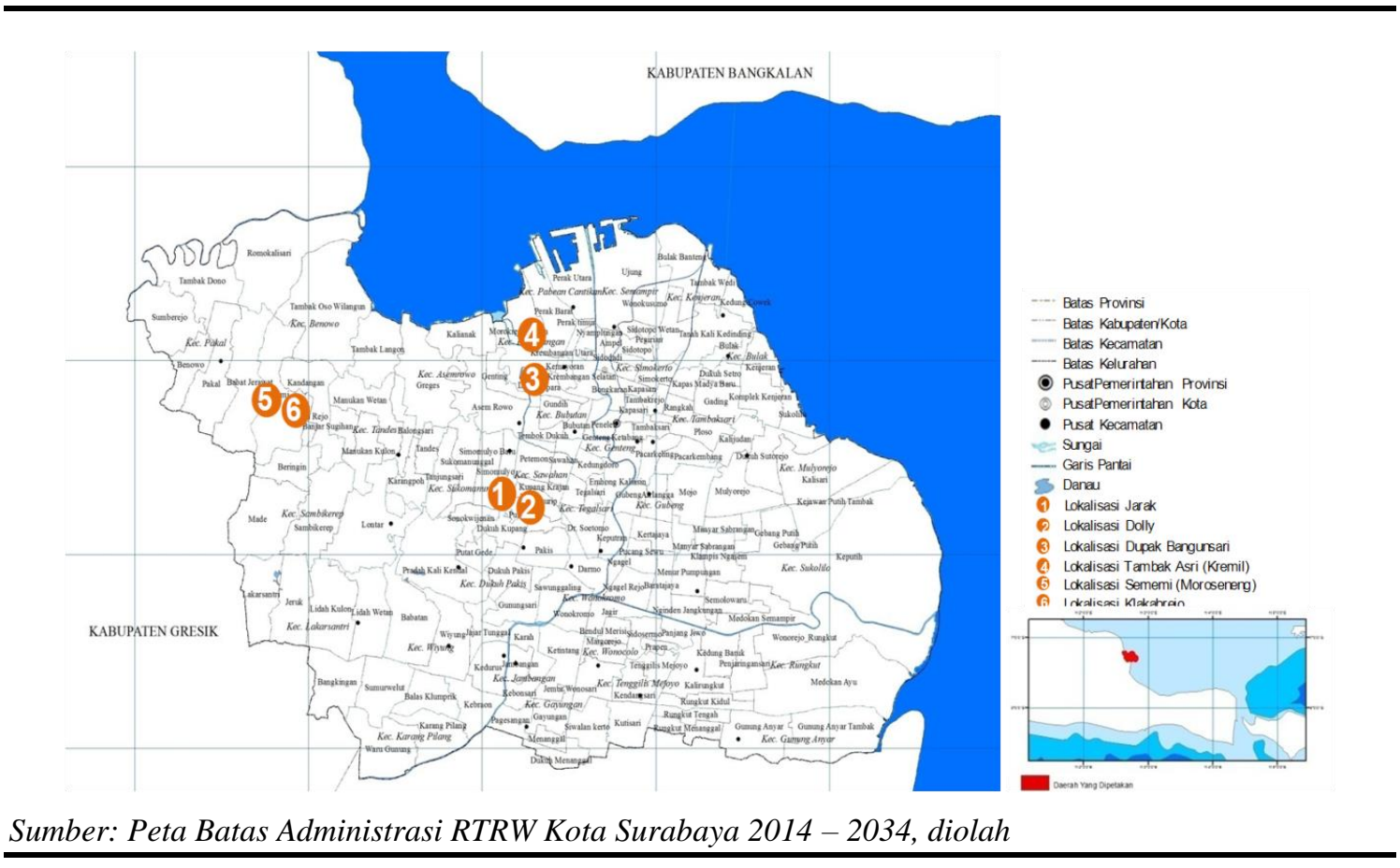

Gambar 1. Peta Persebaran Kawasan Eks Lokalisasi di Kota

Sampai dengan tahun 2014 tersebar enam kawasan eks lokalisasi, yaitu Jarak dan Dolly di Kelurahan Putat Jaya Kecamatan Sawahan; Dupak Bangunsari di Kelurahan Dupak Kecamatan Krembangan; Tambak Asri (Kremil) di Kelurahan Morokrembangan 
Kecamatan Krembangan; Sememi (Moroseneng) di Kelurahan Sememi Kecamatan Benowo; dan Klakahrejo di Kelurahan Klakahrejo Kecamatan Benowo. Dari keenam lokalisasi tersebut, lokalisasi Putat Jaya merupakan lokalisasi terbesar baik dari jumlah wisma dan jumlah PSK (Dinsos, 2014). Seluruh lokalisasi di Kota Surabaya ditutup secara bertahap pada tahun 2012 - 2014 (Dinsos, 2014).

Kelurahan Putat Jaya terdiri dari 15 RW dan 114 Rukun Tetangga (RT) dengan luas wilayah 136 ha. Berdasarkan data monografi Kelurahan Putat Jaya (2016), sampai dengan bulan Maret 2016 jumlah penduduk Kelurahan Putat Jaya adalah sebanyak 53.447 jiwa. Komposisi penduduk berdasarkan angkatan kerja didominasi oleh rentang usia 27-40 tahun yaitu sebanyak 12.632 jiwa atau 29,69\%. Berdasarkan usia sekolah didominasi oleh kelompok usia 19 tahun ke atas yaitu sebanyak 30.839 jiwa atau 63,58\%. Berdasarkan tingkat pendidikan didominasi oleh lulusan SMA yaitu sebanyak 12.435 jiwa atau 34,97\%. Ditinjau dari jenis/kelompok pekerjaan, penduduk Kelurahan Putat Jaya didominasi oleh pelajar/mahasiswa yaitu sebanyak 9.312 jiwa atau 34,29\%, diikuti kelompok ibu rumah tangga sebanyak 6.239 jiwa atau 22,98\%. Kelurahan Putat Jaya didominasi oleh permukiman padat tertata dengan kondisi infrastruktur yang cukup baik.

Pasca penutupan kawasan eks lokalisasi Putat Jaya pada 18 Juni 2014, telah dilakukan peremajaan kawasan pada aspek sosial, ekonomi dan fisik. Bentuk peremajaan tersebut terdiri dari intervensi pemerintah dan peremajaan yang dilaksanakan secara mandiri oleh masyarakat. Pelaksanaan peremajaan tersebut dirangkum dalam Tabel 2.

Tabel 2. Pelaksanaan Peremajaan Kawasan Eks Lokalisasi Putat Jaya

\begin{tabular}{|c|c|c|}
\hline \multirow[b]{2}{*}{ Aspek } & \multicolumn{2}{|c|}{ Peremajaan yang Telah Dilaksanakan } \\
\hline & $\begin{array}{c}\text { Peremajaan dengan Intervensi } \\
\text { Pemerintah }\end{array}$ & Peremajaan oleh Masyarakat \\
\hline $\begin{array}{l}\text { Bina Manusia/ } \\
\text { aspek sosial }\end{array}$ & $\begin{array}{l}\text { - Pelaksanaan bedah buku dan diskusi } \\
\text { keagamaan } \\
\text { - Pemeriksaan dan penyuluhan } \\
\text { mengenai HIV/AIDS, narkoba dan } \\
\text { IMS } \\
\text { - Bantuan pendidikan untuk } \\
\text { melanjutkan sekolah } \\
\text { - Operasi yustisi di tempat kos dan } \\
\text { tempat hiburan } \\
\text { - } \text { Rekrutmen warga terdampak sebagai } \\
\text { tenaga kontrak di Pemerintah Kota } \\
\text { Surabaya }\end{array}$ & - \\
\hline $\begin{array}{l}\text { Bina Usaha/ } \\
\text { aspek ekonomi }\end{array}$ & $\begin{array}{l}\text { - Pelaksanaan pelatihan untuk } \\
\text { pengembangan usaha mandiri } \\
\text { - Pemberian bantuan modal usaha }\end{array}$ & $\begin{array}{l}\text { Sebanyak } 12 \text { UKM telah } \\
\text { mengembangkan usahanya dengan } \\
\text { baik dan membuka lapangan kerja } \\
\text { baru bagi warga terdampak lainnya }\end{array}$ \\
\hline $\begin{array}{l}\text { Bina } \\
\text { Lingkungan/ } \\
\text { aspek fisik }\end{array}$ & $\begin{array}{l}\text { - Pembelian eks wisma sebagai sarana } \\
\text { pemberdayaan masyarakat } \\
\text { - Peningkatan kualitas lingkungan } \\
\text { seperti pavingisasi dan perbaiksan } \\
\text { saluran } \\
\text { - Pengadaan peralatan kebersihan } \\
\text { - Pelimpahan rekening PJU kepada } \\
\text { Pemerintah Kota Surabaya }\end{array}$ & $\begin{array}{l}\text { Penyediaan RTH pada masing- } \\
\text { masing persil bangunan }\end{array}$ \\
\hline
\end{tabular}

Sumber: (Bappeda, 2014)

\section{Aktor yang Berpengaruh dan Berkepentingan dalam Peremajaan}

Pada tahap awal stakeholder analysis dilakukan identifikasi stakeholder kunci. Terdapat dua tipe stakeholder, yaitu stakeholder internal dan eksternal. Stakeholder internal adalah 
instansi/lembaga yang terlibat secara langsung atau berada dalam organisasi yang menentukan kebijakan/melaksanakan peremajaan kawasan eks lokalisasi Putat Jaya. Stakeholder eksternal adalah instansi/lembaga yang tidak terlibat secara langsung atau berada di luar organisasi tersebut. Dari hasil identifikasi diperoleh bahwa stakeholder internal dalam peremajaan kawasan eks lokalisasi Putat Jaya terdiri dari masyarakat (RW 03, RW 06, RW 10, RW 1, RW 12, UKM Keripik, UKM Sepatu, UKM Batik, UKM Sablon, UKM Minuman Rumput Laut) dan Pemerintah Kota Surabaya, sedangkan stakeholder eksternal terdiri dari lembaga kemasyarakatan, BUMN, swasta, akademisi, Pemerintah Pusat dan Pemerintah Provinsi Jawa Timur.

Tabel 3. Pelaksanaan Peremajaan Kawasan Eks Lokalisasi Putat Jaya

\begin{tabular}{|c|c|c|c|}
\hline \multirow{2}{*}{$\begin{array}{l}\text { Tingkat } \\
\text { Pengaruh } \\
\text { Stakeholder }\end{array}$} & \multicolumn{3}{|c|}{ Tingkat Kepentingan Stakeholder } \\
\hline & Sedikit Penting & Cukup Penting & Sangat Penting \\
\hline Sedikit & & - BUMN & \\
\hline Berpengaruh & & - Swasta & \\
\hline Cukup & Lembaga & - Pemerintah Pusat: & Masyarakat: RW 06, RW 10, RW \\
\hline Berpengaruh & Kemasyarakatan & $\begin{array}{l}\text { Kemensos, } \\
\text { Kemenperin } \\
\text { - Pemerintah } \\
\text { Provinsi Jawa } \\
\text { Timur }\end{array}$ & $\begin{array}{l}\text { 11, UKM Sablon, UKM Rumput } \\
\text { Laut }\end{array}$ \\
\hline $\begin{array}{l}\text { Sangat } \\
\text { Berpengaruh }\end{array}$ & Akademisi & & $\begin{array}{l}\text { - Masyarakat: RW 03, RW 12, } \\
\text { UKM Keripik, UKM Sepatu, } \\
\text { UKM Batik } \\
\text { - Pemerintah Kota Surabaya: } \\
\text { Bappeko, Dinsos, Kec. Sawahan, } \\
\text { Kel. Putat Jaya, Bapemas, } \\
\text { Disperdagin, DPBT, DPUCKTR }\end{array}$ \\
\hline
\end{tabular}

Selajutnya, dilakukan pemetaan tingkat pengaruh dan tingkat kepentingan stakeholder. Pemetaan ini dilakukan melalui proses pembobotan dengan pertimbangan hasil wawancara dan tinjauan dokumen kebijakan terkait. Tingkat pengaruh diperoleh dengan mempertimbangkan kekuasaan dan kepemimpinan. Stakeholder dengan kekuasaan dan kepemimpinan tinggi terdiri dari masyarakat RW 03, RW 12, UKM Keripik, UKM Sepatu, UKM Batik, Pemerintah Kota Surabaya dan akademisi. Tingkat kepentingan diperoleh dengan mempertimbangkan posisi dan pengetahuan akan kebijakan. Stakeholder dengan posisi mendukung dan pengetahuan akan kebijakan tinggi terdiri dari masyarakat dan Pemerintah Kota Surabaya.

Dari hasi pemetaan stakeholder, dapat dirumuskan saran tindak lanjut sesuai tingkat pengaruh dan kepentingannya. Stakeholder dengan tingkat pengaruh dan kepentingan sangat tinggi harus bisa dilibatkan sepenuhnya sebagai penentu keberhasilan program peremajaan berbasis masyarakat. Stakeholder dengan tingkat pengaruh tinggi namun tidak terlalu berkepentingan perlu mendapat perlakuan bahwa keberadaan mereka adalah penting, perlu penyampaian informasi dan pemberian apresiasi atas peran mereka. Stakeholder dengan tingkat kepentingan tinggi namun tidak terlalu berpengaruh perlu mendapat pemahaman bahwa kebutuhan mereka sejalan dengan tujuan program dan keterlibatan mereka sangat bermakna.

\section{Preferensi Masyarakat terhadap Peremajaan Kawasan Eks Lokalisasi Putat Jaya}

Preferensi dalam hal ini adalah pendapat masyarakat secara umum terhadap aspek dan komponen dalam peremajaan berbasis masyarakat sehingga dapat diketahui sudut 
pandang masyarakat mengenai arah peremajaan pada kawasan eks lokalisasi Putat Jaya. Pada aspek sosial, masyarakat mengharapkan adanya monitoring yang dilakukan oleh Pemerintah Kota Surabaya secara berkala terutama dalam pemantauan hasil pelatihan peningkatan keterampilan masyarakat. Dari aspek ekonomi, masyarakat menginginkan adanya peningkatan kesempatan kerja dan pendapatan masyarakat pasca penutupan lokalisasi Putat Jaya. Dari aspek fisik, masyarakat menginginkan adanya kelengkapan dan kecukupan sarana prasarana lingkungan yang berkualitas. Beberapa UKM telah berkembang dengan baik namun belum ditunjang oleh prasarana yang memadai. Secara keseluruhan, sebagian besar responden mengharapkan peremajaan kawasan eks lokalisasi Putat Jaya dapat meningkatkan perekonomian warga, khususnya warga terdampak yang sebelumnya bergantung pada kegiatan prostitusi. Masyarakat mengharapkan kondisi peremajaan ke depannya agar kawasan eks lokalisasi Putat Jaya dapat berkembang menjadi kawasan pusat perdagangan serta meningkatkan daya tarik kawasan sehingga dalam jangka panjang dapat memajukan perekonomian masyarakat.

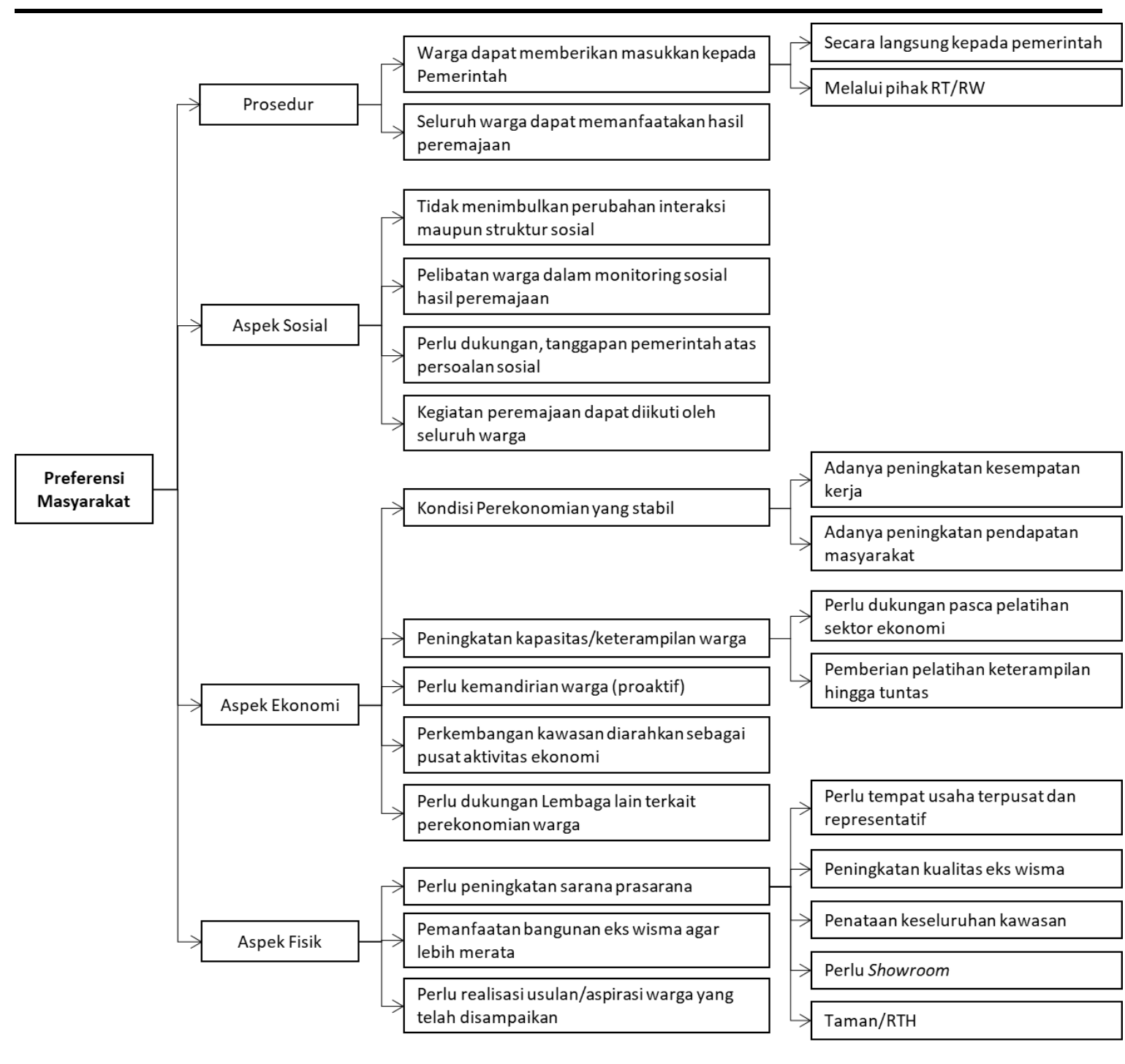

Gambar 2. Skema Analisis Taksonomi Mengenai Preferensi Masyarakat dalam Peremajaan Kawasan Eks Lokalisasi Putat Jaya Berbasis Masyarakat 


\section{Potensi dan Persoalan Peremajaan Berbasis Masyarakat pada Kawasan Eks Lokalisasi Putat Jaya Surabaya}

Potensi dalam peremajaan kawasan eks lokalisasi Putat Jaya merupakan kekuatan masyarakat maupun kondisi wilayah dalam peremajaan yang dapat dikembangkan untuk pencapaian peremajaan kawasan eks lokalisasi Putat Jaya berbasis masyarakat. Kesesuaian antara mekanisme peremajaan berbasis masyarakat dengan kondisi empiris peremajaan dapat membentuk suatu potensi. Karakteristik kawasan dan kebijakan yang dapat menunjang pelaksanaan peremajaan juga menciptakan potensi peremajaan. Persoalan dimaksud merupakan hal-hal dalam peremajaan kawasan eks lokalisasi Putat Jaya berbasis masyarakat yang menuntut jawaban dan memerlukan solusi. Persoalan peremajaan dapat terjadi karena ketidaksesuaian mekanisme peremajaan berbasis masyarakat dengan kondisi empiris, kendala lapangan yang belum memiliki solusi serta kondisi yang belum diatur dalam kebijakan peremajaan kawasan eks lokalisasi Putat Jaya berbasis masyarakat.

Potensi dalam peremajaan kawasan eks lokalisasi Putat Jaya secara umum tersedianya sumber daya dan sifat stakeholder yang kooperatif dalam pelaksanaan peremajaan. Persoalan secara umum yaitu stabilitas perekonomian warga; belum maksimalnya partisipasi dan peran masyarakat dalam peremajaan; dan belum tersedianya fasilitator untuk menjembatani persoalan tersebut. Peran stakeholder khususnya dari pihak swasta, BUMN, lembaga kemasyarakatan yang belum optimal dan belum terdapat upaya untuk pelibatan stakeholder tersebut. Memperhatikan kondisi yang terjadi, rumusan rekomendasi mengarahkan pada perencanaan peremajaan untuk fokus pada aspek ekonomi. Penyediaan fasilitator penting dilakukan untuk pendampingan dan mengoptimalkan peran masyarakat dalam peremajaan. Di samping itu perlu dilakukan upaya pelibatan stakeholder misalnya melalui forum atau sosialisasi program peremajaan.

\section{Penilaian Mekanisme Peremajaan Berbasis Masyarakat pada Kawasan Eks Lokalisasi Putat Jaya Surabaya}

Berdasarkan kajian dari observasi dan wawancara terstruktur, diketahui bahwa mekanisme dan sub mekanisme peremajaan berbasis masyarakat yang terpenuhi terdiri dari:

a. Proses perencanaan

Penggunaan rencana tata ruang kota sebagai landasan umum prioritas pengembangan; Delineasi berdasarkan kebijakan umum pembangunan kota; Penentuan wilayah yang diremajakan memiliki tingkat kepentingan lebih tinggi dari sekitarnya; Penelaahan wilayah untuk memperoleh gambaran spesifik mengenai wilayah perencanaan serta analisis permasalahan dan kemungkinan pengembangannya; Inventarisasi usulan dilakukan melalui dialog masyarakat; Penyusunan program dilakukan secara periodik atau berkala; Pengembangan alternatif konseptual perencanaan peremajaan kota, meliputi peningkatan kesempatan kerja, identifikasi guna lahan dan bangunan, peningkatan nilai visual, tidak mengubah nilai historis dan budaya, penyediaan RTH pasca peremajaan, peningkatan kualitas fisik dan pemerataan utilitas umum, penyediaan pembiayaan dan penyediaan akses bagi sumber daya pendukung.

b. Proses pelaksanaan

Penyadaran masyarakat melalui pelatihan

c. Proses pengawasan dan pengendalian

Monitoring dan evaluasi partisipatif

Sedangkan mekanisme dan sub mekanisme peremajaan berbasis masyarakat yang tidak terpenuhi terdiri dari:

a. Proses perencanaan

Delineasi, penelaahan wilayah, analisis dan pemetaan sosial serta penyusunan program tidak dilakukan oleh masyarakat dengan pendampingan fasilitator; Penentuan wilayah 
tidak berdasarkan penyepakatan kriteria secara bersama; Pengembangan alternatif konseptual perencanaan peremajaan kota belum dapat memenuhi prasyarat peningkatan pendapatan masyarakat dan penyediaan sarana yang terkait dengan pergerakan; Sosialisasi belum dilakukan secara luas

b. Proses pelaksanaan

Penerapan rencana kegiatan kelompok; Kebersamaan dalam pemanfaatan hasil peremajaan; Tidak terdapat lembaga yang efektif dalam pelaksanaan pembangunan

c. Proses pengawasan dan pengendalian

Pemandirian masyarakat sampai dengan mampu mengelola kegiatan secara mandiri; Pengorganisasian masyarakat dan advokasi kebijakan; Politisasi kebijakan, untuk memperoleh dan melestarikan kebijakan peremajaan kawasan melalui pembangunan berbasis masyarakat.

Sebanyak 20 dari 34 poin mekanisme dan sub mekanisme peremajaan berbasis masyarakat telah terpenuhi $(58,8 \%)$ dan sebanyak 14 dari 34 poin mekanisme dan sub mekanisme peremajaan berbasis masyarakat tidak terpenuhi $(41,2 \%)$. Dalam proses perencanaan, delineasi, penelaahan wilayah, analisis dan pemetaan sosial serta penyusunan program belum melibatkan masyarakat, sehingga Pemerintah Kota Surabaya (Dinas Sosial) perlu menyiapkan tenaga fasilitator yang terkualifikasi dan berkompeten untuk dapat mendampingi masyarakat secara intensif dalam keseluruhan proses tersebut. Penentuan wilayah tidak berdasarkan penyepakatan kriteria secara bersama, untuk itu penentuan wilayah agar dilaksanakan oleh Pemerintah Kota Surabaya (Badan Perencanaan Pembangunan, Dinas PU Cipta Karya dan Tata Ruang, Dinas Sosial, Kecamatan Sawahan, Kelurahan Putat Jaya) bersama dengan masyarakat dan stakeholder terkait lainnya, dengan mempertimbangkan aspek ekonomi wilayah. Dalam proses perencanaan ini juga ditemukan bahwa pengembangan alternatif konseptual perencanaan peremajaan kota belum dapat memenuhi peningkatan pendapatan masyarakat dan penyediaan sarana yang terkait dengan pergerakan, sehingga masyarakat (UKM) dan Pemerintah Kota Surabaya (Dinas Perdagangan dan Perindustrian, Badan Pemberdayaan Masyarakat dan Keluarga Berencana) perlu menjaga dan meningkatkan pola ekonomi yang telah terbentuk. Selanjutnya, Pemerintah Kota Surabaya perlu melakukan pendampingan pada UKM secara intensif. Akademisi dan Pemerintah Kota Surabaya (Badan Perencanaan Pembangunan, Kecamatan Sawahan, Kelurahan Putat Jaya) perlu melakukan percepatan terkait realisasi pengembangan kampung ekonomi. Sosialisasi peremajaan oleh pemerintah belum dilakukan secara luas. Dalam hal ini fasilitator kembali memegang peranan penting. Masyarakat dengan didampingi fasilitator dan Pemerintah Kota Surabaya (Badan Perencanaan Pembangunan, Dinas Sosial, Kecamatan Sawahan, Kelurahan Putat Jaya) perlu melakukan sosialisasi kepada warga setempat, warga sekitar, serta stakeholder terkait mengenai konsep, program dan kegiatan peremajaan kawasan eks lokalisasi Putat Jaya yang akan dilakukan serta gambaran kontribusi yang dapat dilakukan pihak-pihak terkait dalam peremajaan

Dalam proses pelaksanaan, penerapan rencana kegiatan kelompok belum dilaksanakan. Rencana kegiatan disusun oleh Pemerintah Kota Surabaya. Untuk menerapkan rencana kegiatan kelompok, masyarakat perlu membuat penyesuaian rencana kegiatan yang disusun oleh Pemerintah Kota Surabaya berdasarkan kondisi masyarakat termasuk membuat pengaturan sistem kerja. Kebersamaan dalam pemanfaatan hasil peremajaan belum terwujud sepenuhnya karena terdapat kebijakan pemanfaatan eks wisma secara spesifik. Untuk itu Pemerintah Kota Surabaya (Dinas Pengelolaan Bangunan dan Tanah) perlu menyusun kebijakan pemanfaatan eks wisma dan masyarakat melakukan pemetaan aktivitas sosial ekonomi yang berkembang beserta kebutuhan ruangnya. Belum adanya lembaga yang efektif dalam pelaksanaan pembangunan terlihat dari peremajaan pada aspek ekonomi bahwa beberapa UKM tidak dapat berkembang/melanjutkan 
usahanya. Dalam hal ini Pemerintah Kota Surabaya (Dinas Perdagangan dan Perindustrian, Badan Pemberdayaan Masyarakat dan Keluarga Berencana) perlu melibatkan lembaga kemasyarakatan untuk melakukan pendampingan kepada UKM. Di samping itu, UKM yang telah mandiri memberikan saran dan bantuan kepada UKM yang belum mandiri.

Dalam proses pengawasan dan pengendalian, pemandirian masyarakat sampai dengan mampu mengelola kegiatan secara mandiri belum sepenuhnya dilaksanakan, sehingga Pemerintah Kota Surabaya (Dinas Perdagangan dan Perindustrian, Badan Pemberdayaan Masyarakat dan Keluarga Berencana) perlu memberikan pendampingan kepada UKM sampai dapat menjalankan usahanya secara mandiri dan melakukan pemantauan intensif hasil peremajaan. Pengorganisasian masyarakat dan advokasi kebijakan belum dilaksanakan. Sebagai langkah awal, Pemerintah Kota Surabaya (Badan Perencanaan Pembangunan) perlu membuat kajian terkait urgensi dan pola pelaksanaan proses pengorganisasian masyarakat untuk advokasi kebijakan dalam konteks dukungan politik dan legitimasi dari elit masyarakat. Politisasi kebijakan untuk memperoleh dan melestarikan kebijakan peremajaan kawasan eks lokalisasi Putat Jaya melalui pembangunan berbasis masyarakat belum dilaksanakan, sehingga Pemerintah Kota Surabaya (Badan Perencanaan Pembangunan) perlu mempublikasikan kebijakan peremajaan kawasan eks lokalisasi Putat Jaya berbasis masyarakat melalui forum-forum publik.

Penelitian ini memperkuat temuan penting terkait proses dan pendekatan perencanaan berbasis masyarakat. Meskipun bukan bersifat multiskala sebagaimana kasus di Enning Road project in Guangzhou, China (Zhang \& Li, 2016) dan praktek peremajaan dilakukan berbasis masyarakat dimana masyarakat lebih berperan (bukan top-down), serta pemerintah hanya berperan sebagai fasilitator, namun kerumitan proses peremajaan tetap terjadi dengan banyaknya kepentingan (dan power relation) dan potensi konflik antara masyarakat dan aktor diluar lingkungan kawasan peremajaan (Tian \& Yao, 2018). Penelitian ini berkontribusi pada eksplorasi hubungan timbal balik fungsi dan elemen perencanaan dan peran pemangku kepentingan sebagai kesenjangan penelitian terkait peremajaan kota saat ini yang sebagian besar hanya fokus pada elemen pembentuk perencanaan atau dari aspek peran stakeholder (Zheng et al., 2014), serta mengkaji relasi (power relation) antarstakeholder (Tian \& Yao, 2018). Dalam konteks hubungan timbal balik antara komponen perencanaan dan aktor terkait dan relasi antarstakeholder, penelitian ini menunjukkan adanya potensi peremajaan kota yang sejalan dengan pemberdayaan masyarakat. Penelitian ini semakin memperkaya arah penelitian peremajaan kota yang berkelanjutan di masa depan, berkenaan dengan penerapannya pada perspektif yang lebih komprehensif dan metode yang lebih obyektif (Zheng et al., 2014)

\section{KESIMPULAN}

Upaya peremajaan kawasan tidak hanya menekankan pada perubahan fisik kawasan, namun harus didorong dari perubahan dari tuntutan kegiatan/ektivitas ekonomi maupun kekuatan-kekuatan sosial yang ada di masyarakat. Peremajaan kawasan berbasis masyarakat harus bertitik tolak pada rakyat (people centered development) yang terlibat dalam setiap proses pembangunan/peremajaan dari tahapan penetapan dan pengenalan wilayah kerja, sosialisasi kegiatan, penyadaran masyarakat dan pengorganisasian masyarakat.

Tidak terpenuhinya peremajaan berbasis masyarakat pada peremajaan kawasan eks lokalisasi Putat Jaya pada dasarnya disebabkan karena belum terdapat informasi mengenai mekanisme peremajaan berbasis masyarakat dan kendala waktu bahwa peremajaan kawasan eks lokalisasi Putat Jaya harus segera dilaksanakan pasca penutupan kawasan lokalisasi. Secara teknis, tidak terpenuhinya mekanisme tersebut disebabkan karena belum tersedianya tenaga fasilitator yang dapat memfasilitasi masyarakat untuk dapat lebih 
berperan aktif dalam peremajaan serta masih terdapatnya dominasi peran Pemerintah dalam pelaksanaan peremajaan.

\section{DAFTAR PUSTAKA}

Adams, D., \& Hastings, E. M. (2001). Urban Renewal in Hong Kong: Transition from Development Corporation to Renewal Authority. Land Use Policy, 18(3), 245-258. https://doi.org/10.1016/S02648377(01)00019-9

Bappeda. (2014). Grand Design Penataan Kawasan Eks Lokalisasi Kelurahan Putat Jaya Kecamatan Sawahan. Badan Perencanaan Pembangunan Kota Surabaya.

Chun Tie, Y., Birks, M., \& Francis, K. (2019). Grounded Theory Research: A Design Framework for Novice Researchers. SAGE Open Medicine, 7, 1-8. https://doi.org/10.1177/2050312118822927

Clark, J., \& Wise, N. (2018). Urban Renewal, Community and Participation; Theory, Policy and Practice (J. Clark \& N. Wise (eds.)). Springer. https://doi.org/https://doi.org/10.1007/978-3-319-72311-2

Couch, C. (1990). Urban Renewal: Theory and Practice (1st ed.). Macmillan.

Couch, C., Sykes, O., \& Börstinghaus, W. (2011). Thirty Years of Urban Regeneration in Britain, Germany and France: The importance of Context and Path Dependency. Progress in Planning, 75, 1-52. https://doi.org/10.1016/j.progress.2010.12.001

Creswell, J. W. (2014). Research Design: Qualitative, Quantitative, and Mixed Methods Approaches 4th (4th ed.). Sage Publications, Inc.

Dinsos. (2014). Program penanganan lokalisasi di Kota Surabaya: Paparan MDGs. Dinas Sosial Kota Surabaya.

Korten, D. C. (1984). People Centered Development: Contributions toward Theory and Planning Frameworks (R. Klauss (ed.)). Kumarian Press.

Lai, L. W. C., Chau, K. W., \& Cheung, P. A. C. W. (2018). Urban Renewal and Redevelopment: Social Justice and Property Rights with Reference to Hong Kong's Constitutional Capitalism. Cities, 74, 240248. https://doi.org/10.1016/j.cities.2017.12.010

Mardikanto, T. (2010). Model-model Pemberdayaan Masyarakat.pdf. UNS Press.

Mikkelsen, B. (2001). Metode Penelitian Partisipatoris dan Upaya-upaya Pemberdayaan: Sebuah Buku Bagi Para Praktisi Lapangan. Yayasan Pustaka Obor Indonesia.

Schmeer, K. (2000). Stakeholder Analysis Guidelines - Section 2. In Policy Toolkid for Strengthening Health Sector Reform. USAID. https://doi.org/10.1093/heapol/15.3.338

Taufiq, M., Natalivan, P., Suhirman, S., \& Kombaitan, B. (2019). Menemukan Kembali Pembaruan Perkotaan Berbasis Pengembangan Masyarakat: Studi Penanganan Pemukiman Kumuh Di Perkotaan Indonesia. Tataloka, 21(4), 649-659. https://doi.org/10.14710/tataloka.21.4.649-659

Theresia, A., Andisi, K. S., Nugraha, P. G., \& Mardikanto, T. (2014). Pembangunan Berbasis Masyarakat: Acuan Bagi Praktisi. Akademis, dan Pemerhati Pengembangan Masyarakat. Alfabeta.

Tian, L., \& Yao, Z. (2018). From State-dominant to Bottom-up Redevelopment: Can Institutional Change Facilitate Urban and Rural Redevelopment in China. Cities, 76, 72-83. https://doi.org/10.1016/j.cities.2018.01.010

Wang, Y., Li, J., Zhang, G., Li, Y., \& Asare, M. H. (2017). Fuzzy Evaluation of Comprehensive Benefit in Urban Renewal Based on the Perspective of Core Stakeholders. Habitat International, 66, 163-170. https://doi.org/10.1016/j.habitatint.2017.06.003

Wedchayanon, N., \& Chorkaew, S. (2014). Sufficiency Economy and People-centered Development: a Case of Huay Sai Royal Development Project in Thailand. European Journal of Training and Development, 38(9), 822-844. https://www.emerald.com/insight/content/doi/10.1108/EJTD-10-2013-0118/full/html

Zhang, C., \& Li, X. (2016). Urban Redevelopment as Multi-scalar Planning and Contestation: The Case of Enning Road project in Guangzhou, China. Habitat International, 56, 157-165. https://doi.org/10.1016/j.habitatint.2016.05.008

Zheng, H. W., Shen, G. Q., \& Wang, H. (2014). A review of Recent Studies on Sustainable Urban Renewal. Habitat International, 41, 272-279. https://doi.org/10.1016/j.habitatint.2013.08.006 